\title{
Language Aspects in Hypnosis Dental Therapy: Pragmatic and Stylistic Studies
}

\author{
Nani Darmayanti \\ Dian Ekawati \\ Wagiati \\ Erlina \\ Faculty of Cultural Sciences \\ Universitas Padjadjaran \\ Indonesia
}

\begin{abstract}
The research titled "Language Aspects in Hypnosis Dental Therapy: Pragmatic ans Stylistic Studies" focuses on several language aspects used in the practice of hypnosis dental therapy. With using qualitative method and descriptive data presentation, this research uses the theories of Pragmatics, Stylistics, and Conversation Analysis aiming at (1) describing varieties and types of speech act along with (2) figure of speech used in the therapy when performing the hypnosis dental treatment. The data were collected from the conversations between the therapist and her patients in the situaton context of medical examination. The result of the research shows that in the hypnosis dental practice there are several steps namely Pre-Induction, Induction, Deepening, Suggestion, Termination, and Post-Hypnotic marked by systematic language aspects based on the speech act and figure of speech. (1) The forms and types of speech act found in the hypnosis dental therapy are illocutionary act (speech intention) direct-commanding (directive), direct-stating (assertive), and indirect-stating (assertive). Furthermore, perlocutionary act (speech response) may be realized in verbal and nonverbal. (2) figure of speech used in the hypnosis dental therapy are climax, parallelism, antithesis, and repetition. All language strategies used intend to give suggestion in order for the patients to feel less painful and calm during the medical treatment.
\end{abstract}

Keywords: language, hypnosis, pragmatics, figure of speech, dentistry

\section{Introduction}

Hypnosis is a process when one's mind is relaxed and easily to accept suggestion given. The hypnotist does not control the mind of the hypnotized person, but instead the hypnotized one is allowing himself to accept willingly suggestions given. In addition, the hypnotized person is conscious. Only in many shows, the hypnotized person closes his/her eyes. Even though the suggestion given by the hypnotist is "to sleep", the hypnosis sleep (trance) is different than the common sleep. In the hypnosis sleep, one may still hear, feel, and accept stimuli given by the hypnotist (Nurhadi, 2013).

Wong and Hakim (2009) in Nurhadi (2013) state that the hypnotized person only shift consciousness from conscious to subconscious. Relating to hypnosis, Heller and Steele (2005) argue that the hypnosis process is the result of the interaction between verbal and analytic functions conducted by the left hemisphere and the creative and nonverbal functions conducted by the right hemisphere.

The hypnosis study has developed for quite some time and been used in medical practice. Watkins (1983) in the book titled "The Handbook of Clinical Health Psychology" finds that hypnosis has been used as a medical medium since a long time ago. The Psychology is the most academic field to benefit from this hypnosis therapy. Furthermore, in its development, this therapy is also used for medical purpose in Dentistry. The hypnosis practice is used by a dentist to suggest his/her patients in order for the patients feel less painful when receiving medical treatment. Hypnotizing patients in Dentistry later is called Hypnodontic therapy (Dental Hypnosis). 
Generally, the hypnosis therapy is defined as a hypnotherapy technique conducted to patients resulting in deep relaxation by going through therapeutic communication process both verbal and nonverbal and it aims at influencing the patients to condition their minds. To achieve this goal, language becomes a crucial aspect because the whole process of this hypnosis therapy uses language as the communication medium to deliver suggestion. Based on the assumption that language is systematic, then the process of hypnosis therapy is assumed to be systematic as well relating to language system which becomes the medium allowing one accepts suggestion with certain language strategies.

Considering how the intimate relation between language and hypnosis therapy is, it will be quite interesting to be studied on how the language aspect conveyed in that communcation so that it may suggest the patient for feeling less painful during the medical treatment. The Linguistics disciplines that can reveal the language system used in the hypnosis therapy are Pragmatics and Stylistics, in particular relating to speech act and figure of speech to see the conversational patterns in hypnosis therapy.

Hickey (1993) states that Pragmatics is directly interested in, not language, by what a person does with language: its use and users. In addition, Pragmatics also concerns with the means in which information or message is managed to communicate effectively

The Pragmatics study is limited by Yule (1996) as (1) the study of speaker intention, (2) the study of contextual meaning, (3) the study of how more communicated than is said, (4) the study of expression from distance and relation, and (5) the study of relation between linguistic features and their use.

Meanwhile, Leech (1993:13) states that Pragmatics closely relates to speech act because it studies meaning related to speech situation.the speech act is part of Pragmatics, while Pragmatics relates to linguistic performance. Therefore, it can be described that speech act is part of linguistic performance. The illocutionary act, based on its types, is classified into five speech forms, considered based on its communicatuve functions, namely (1) Assertives or Representatives, (2) Directives, (3) Expressives, (4) Commisives, and (5) Declarations.

The Pragmatics study has become the scientific cover for conversation analysis study to reveal more detailed patterns and steps in a communicative situation such as hypnosis therapy communication. The conversation analysis developed by Sacks, Schegloff, and Jeffernson (1974) mentions that a conversation has a structured and patterned system, in general consisting of conversational opening, content and theme discussion, along with closing. Meanwhile, hypnosis is also defined as a state of mind when the logic-analysis function of mind is reduced so that it allows an individual to enter into the consciousness (Fachri, 2008: 12).

Table 1. Four Categories of the Brainwaves

\begin{tabular}{l|l}
\hline $\begin{array}{l}\text { Beta } \\
(14-100 \mathrm{~Hz})\end{array}$ & $\begin{array}{l}\text { Cognitive, analytic, logic, left brain, concentration, sorting, prejudice, } \\
\text { conscious mind } \\
\text { Active, anxious, worried, stressed, fight or flight, disease, cortisol, } \\
\text { norepinephrine } \\
\text { Focused, relaxation, meditative, focus alertness, superlearning, early } \\
\text { subconscious mind } \\
\text { Sincere, comfortable, calm, relaxed, rested, satisfied, fresh, happy, } \\
\text { endorphine, serotonine }\end{array}$ \\
\hline Theta & $\begin{array}{l}\text { Very focused, deep- meditation, problem solving, dream, intuition, } \\
\text { deep subconscious mind } \\
\text { Sincere, creative, integrative, silent, imaginative, catecholamines, } \\
\text { AVP (arginine-vasopressin) }\end{array}$ \\
\hline $\begin{array}{l}\text { Delta } \\
(0,1-3,9 \mathrm{~Hz})\end{array}$ & $\begin{array}{l}\text { Sleep tight (without dream), non-physical state, collective } \\
\text { subconscious mind } \\
\text { No mind and feeling, cellular regeneration, HGH (Human Growth } \\
\text { Hormone) }\end{array}$ \\
\hline
\end{tabular}


Wong and Hakim (2009: 3-4) state that hypnosis or also called trance condition may be defined as a relaxed, focused or concentrated condition. Hypnosis is assumed as a condition similar to sleep or a state when mind is subconscious. The hypnosis condition is also a particular state when human brain can easily accept suggestions.

Based on Physics, these condition relate closely to the state of brainwaves. According to Sentanu (2007: 70), if recorded with brainwaves recorder, EEG (Electroencephalogram), the brain 46 can emit waves in accordance to the state of one's mental. The result of the recording mentions four categories of the brainwaves.

Based on the brief explanation above, it is confirmed that language, speech act, and hypnosis therapy relate closely to each other. Therefore, it can be stated that this research aims at revealing language strategies in the hypnosis therapy communication in general. The theories used to analyze types of speech act are Austin (1962), Yule (1996), Wijana (1996), Leech (1983), and Ibrahim (1993), the conversation analysis by Sacks, Schegloff, and Jefferson (1974); as well as the theories of Scarvaglieri (2015), Ehlich (1998), Rehbein/Kameyama (2004), and Redder (2008) to complete the speech responses analysis.

\section{Methodology}

The research used qualitative method. The method is a procedure resulting descriptive data in written or oral data in speech community (Djajasudarma, 1993). The element described in this research is oral data transcribed that exist in the hypnosis dental communication between a therapist and a patient during a medical treatment .

Meanwhile, the technique used was Involved Conversation Observation Technique and Writing Technique (Sudaryanto, 1993). The Involved Conversation Observation Technique (ICOT) meant that the researchers are the observers observing earnestly the prospective data formed and conveyed in the linguistic events outside the researchers (Sudaryanto, 1994). After using ICOT, the researchers used writing technique, namely writing on data card followed by classification. The writing technique was used to collect hypnotherapy speech data in Indonesian from writtern source.

The data source of the research is written speech variety. The determination of data source was based on the consideration that written speech variety was more secured than the oral one was, reflecting formal, steady and planned language (Ochs, 1979) and this procedure was allowed because the language studied had already had writing system (Samsuri, 1983: 169). For such purpose, the written speech variety in the hypnotherapy training module was used and also was taken from the hypnodontic speech of a dentist when conducting the hypnosis therapy to her patient.

\section{Findings and Discussion}

The Pragmatics becomes the scientific cover for the Conversation Analysis to reveal the more detailed patterns and steps in a communication situation such as the hypnosis therapy communication. The conversation analysis developed by Sacks, Schegloff, and Jefferson (1974) mentions that a conversation has a structured and patterned system which in general consists of conversational opening, content and theme discussion along with closing. In the hypnosis therapy, there are also typical conversation structures as said by Wong and Hakim (2009: 22-47) namely: (1) preinduction; (2) induction; (3) deepening; (4) depth level test; (5) suggestion; (6) termination; and (7) posthypnotic. In each step of the hypnosis therapy, particular language strategies are used as well.

\subsection{Speech Act in Hypnosis Therapy}

\subsubsection{Forms of Speech Act}

Searle (1983) says that in the practice of language use by society, there are at least three types of speech act that must be understood comprehensively, namely locutionary act (utterance), illocutionary act (speech intention), perlocutionary act (speech effect). 
The locutionary act is the speech performance with words, phrases, and sentences. This speech act is also called as "The Act of Sayong Something". In this act, the intention and function of the speech delivered by the speaker are not considered. The illocutionary act is the act of doing something with certain intention and function as well. This speech act is also called as "The Act of Doing Something". In this act, the intention and function of the speech delivered by the speaker are studied. The perlocutionary act is the act of affecting listener. This speech act is also called as "The Act of Effecting Someone".

The illocutionary act based on its forms is classified into five different speech forms which is considered from its communicative fucntion, namely (1) Assertives or Representatives, (2) Directives, (3) Expressives, (4) Commisives, and (5) Declarations. Nevertheless, the analysis result in the hypnosis dental communication only found three types, they are assertives, directives, and expressives. Thus, the analysis only focused on these thrre types of speech act.

\section{a. Assertives Speech Act}

The assertives speech act is a speech act describing the speaker's belief adapted into reality. This is in accordance with Yule (1996) stating that assertives speech act (representatives) is a speech act describing the matter of external reality believed by its speaker. This speech act functions to inform people regarding a fact, confirmation, conclusion, and description. In other word, in assertives speeach act, the speaker makes the words or utterances be the same as the reality of the world. The assertives speech acts include stating, suggesting, boasting, complaining, and claiming. In the hypnosis dental communication, the assertives speech act used is the assertives speech act of stating as the following analysis.

(1) Saya akan melakukan sebuah rangkaian kegiatan hipnodontik atau hipnosis dalam bidang kedokteran gigi.

(I will conduct a series of hypnodontic activities or hypnosis in Dentistry.)

Proses hipnodontik ini merupakan rangkaian proses yang melibatkan saya sebagai mitra Bapak agar tujuan akhir yaitu kondisi relaks atau santai dapat tercapai. Bagaimana apakah sepaham dengan saya? Ya, bagus bila sepaham

(The process of hypnodontic is a process involving I as your partner with the goal resulting in calm and relaxed state. Do you understand? Yes, very good if so)

Data (1)-(2) are the utterances stated by a dentist to her patient in the introduction step in hypnosis dental communication. Data (1) is a hypnodontic statement informing patient about the treatment that will be conducted or informing patient on what the hypnosis dental treatment is.

The analysis result above shows that in the introduction step, a hypnodontist generally uses the type of Assertives-Stating speech act. The result also shows that in the beginning of the communication (introduction), a hypnodontist gives more initial information about the treatment that will be conducted to her patient. The initial information refers to assertives-stating utterances functioning to avoid the patient's misunderstanding toward the hypnodontic practice. In general, the assertives-stating speech acts are realized in declarative senteces by giving information. In the following is the pattern of assertive-stating speech act.

\section{b. Directives Speech Act}

The directives speech act contains the speaker's desire for the listener to do something. Therefore, the directives speech act is a statement of what the speaker wants (Yule 2006: 93). Performnative verb belonged to the directives speech act are ordering, commanding, requesting, advising, and recommending. In the hypnosis dental communication, the directives speech act used is directive-commanding speech act as in the following analysis.

(3) Santai ya, Pak, relaks....

(Just calm yes, Sir, relax...)

(4) Pak, silakan dilihat gambar yang berputar di depan sana...

(Sir, please look at the spinning picture a head..) 
Data (3) is a directive-commanding speech act stated by a hypnodontist to her patient marked by the verbs santai (calm) and relaks (relax). Data (4) is a hypnodontist commanding utterance to her patient to follow the instruction given, namely to look at a certain picture to begin the hypnosis dental treatment, marked by the verb+kan silakan (please).

Therefore, the analysis result above shows that in the effort to begin the hypnosis step to the patient, a hypnodontist always uses directive-commanding speech act strategy which in general is realized in imperative sentence using performative verbs such as root verb/root verb $+k a n /$ root verb $+l a h$. In the following is the pattern of commanding speech act in hypnodontic therapy.

\section{d. Expressives Speech Act}

According to Yule (2006: 93), in expressives speech act there is a statement describing what the speaker feels. This speech act reflects psychological statements of the speaker toward a situation. Performative verbs including to this speech act are thanking, congratulating, pardoning, blaming, praising, and condoling. In the hypnodontic therapy, the expressive speech act used is expressives-praising speech act as shown in the following analysis.

Okey bagus, nafasnya diatur ya, bagus, ambil nafas dalam ya bagus lalu buang perlahan, keluarkan dari mulut perlahan dan habiskan,ya bagus, lagi diulang... ya bagus... bagus sekali... Okey bagus

(Okay good, control your breath, good, take a deep breath yes good then exhale slowly, exhale from mouth slowly and all of it, yes good, repeat...yes good...very good...Okay good)

(6) Kini Bapak merasa tenggelam kedalam bumi.... Ya bagus, bagus sekali... sekeliling Bapak sunyi lalu senyap.Bagus, ya bagus sekali.

(Now you feel drowned to the earth...Yes good, very good....all around you is quiet then silent. Good, yes very good)

Data (5)-(6) show the expressive-praising speech act used by a hypnodontist in the hypnodontic therapy. All data above are part of the hypnosis dental during the treatment step. Data (6) uses expressive-praising speech act realized in declarative sentences containing repeated adjectives such as very bagus sekali (very good) and bagus (good). Data (7) also uses expressive-praising speech act realized in declarative sentences containing repeated adjectives such as bagus sekali (very good) and bagus (good).

Therefore, the analysis result above shows that in the effort to begin the hypnosis step in the patient, a hypnodontist, besides always using directives-commanding speech act, also always uses appreciative utterances in which the patient obeys the commands given by the hypnodontist through the expressives-praising speech act strategy. The praises delivered by the hypnodontist generally are in the form of declarative sentences containing adjectives such as bagus (good), bagus sekali (very good), sangat bagus (very good), semakin bagus (getting better), and luar biasa (extraordinary).

These all expressives-praising strategies aim to ease the hypnodontist to take the patient into his deeper subconscious so that he will not feel any pain during the medical treatment. When the patient reaches the quite relaxed state, the patient will be able to receive pain management (managing the pain). This kind of process is conducted with distracting the perception of the patient's pain toward the comfortable one. In addition, praising may give faith to the client that the hypnodontist conducts appropriate hypnosis process so that the client is easier to take suggestions.

\subsubsection{Types of Speech Act}

According to (Wijana and Rohmadi, 2009: 27) types of speech act are divided into two, namely direct speect act and indirect speech act. The direct speech act is when a declarative sentence functions conventionally to inform something, interrogative sentence to ask, and imperative sentence to command, persuade, appeal, and so on 
(Eijana and Rohmadi, 2009: 27). According to Wijana and Rohmadi (2009: 27), to speak politely, command may be realized as a declarative or interrogative sentence so that the one who is asked does not feel being ordered. If this happens, it forms indirect speech act.

\section{a. Direct-Commanding Speech Act}

(7) Saya beri balon sebanyak sepuluh di tangan kanan Bapak, nih pegang ya balonnya, ya bagus... pegang lebih erat..! Saya tambah seratus balon gas, ya bagus.... balon gas ini akan membuat tangan kanan Bapak ringan dan terangkat ke atas oleh balon gas

I give ten balloons on your right hand, hold the ballons, yes good....hold tighter..! I add a hundred gas balloons, yes goood...these gas balloons will make your right hand lighter and be lifted up by the gas balloons

(8) Ya sekarang tangan Bapak terangkat. Luruskan tangan Bapak ke muka, ya lurus ke muka. Bagus! Nah, sekarang balon gas itu akan saya gunting dan tangan Bapak jatuh ke bawah Yes now your hand is lifted up. Straighten your hand to your face, yes straighten to the face. Good! Then, now I will cut the gas balloons and your hand will fall down

Data (7)-(8) are commanding speech acts stated directly. It means that there are comanding speech acts stated in formal sentences in the form of imperative sentences marked by the existing of the verbs pegang (hold) and luruskan (straighten). These can be observed in the sentences "nih pegang ya balonnya, ya bagus... pegang lebih erat..!" (hold the balloons, yes good...hold tighter) and "Luruskan tangan Bapak ke muka, ya lurus ke muka. Bagus!"(Straighten your hand to your face, yes straighten to the face. Good!). these types of direct commands will work on he who in particular has high suggestivity or has already enter into hypnosis state. The direct commands are easier to comprehend since there is no need to pay attention to the intention of the utterance delivered by the therapist

\section{b. Direct-Stating Speech Act}

(9) Saya akan menjelaskan keseluruhan rangkaian proses hipnodontik ini.

I will explain the whole series of this hypnodontic process.

(10) Bapak dapat merasakan dengan jelas perbedaannya dengan tangan kiri.

You may feel distinctively the difference with your left hand.

Data (9)-(10) are stating speech acts delivered directly. It means that the speech acts intend to state something in the form of affirmative sentences marked by the verb menjelaskan (explain) and merasakan (feel). The statements from these two data only inform or tell something. In the data (11) for instance, the hypnodontist states that she will explain the whole series of hypnodontic process. It is likewise in the data (12), the hypnodontist inform that the patient's right hand has already been numb (due to hypnosis) compared to the patient's left hand.

\section{c. Indirect-Stating Speech Act}

(11) Bapak mengantuk tak dapat ditahan lagi... bila saya menghitung sampai tiga, Bapak akan menutup mata dan tidur.... Ya... satu... mata semakin berat... dua... Bapak tak kuat membuka mata lagi... tiga...tutup mata Bapak dan tidur...tidur...Bapak terus tidur....

You will be getting sleepy more and more...if I count till three, you will close your eyes and sleep...yes...one...youe eyes are getting heavier...two...you cannot open your eyes anymore...three...close your eyes and sleep....sleep...you keep sleeping...

(12) Kini Bapak merasakan tangan kanan Bapak semakin ringan, semakin ringan, ya semakin ringan, ya bagus semakin ringan.

Now you feel your right hand is getting lighter, lighter, yes getting ligther, yes good lighter. 
Data (11)-(12) show the types of indirect-stating speech act. They are stating something but with other intentions, namely commanding. This speech act is also called as indirect speech act because the commanding intention is realized in declarative sentence. In the data (11), the hypnodontist gives information that the patient is getting sleepy. Even though, the information commands to become sleepy until he falls asleep. It is the same as data (12), the hypnodontist also informs that the patient's hand is getting lighter. Even though in the statements, it conveys suggestion tocommand the patient to relax his hand. Therefore, in the hypnodontic, a statement may be used to command.

\section{d. Speech Act Response (Perlocutionary Act)}

The response in Pragmatics is also called as perlocutionary act upon the locutionary and illocutionary acts conducted in an interaction between the speaker and listener, in the context of this research they refer to the dentist and her patient. The responses toward the dentist's utterance may be conducted both verbally and nonverbally

The responses are the result of the relation between language speech form and the mental process as stated by Scarvaglieri (2015) referring as well to the result of Ehlich 's empirical research (2008). Since the hypnosis process, in particular dental hypnosis, is to check the patient's psychological mental state and take it into the subsconsciousness, then the doctor's utterances also has similar goal and the responses of the patient emerge from his mental state during the hypnosis process.

Scarvaglieri (2015) mentions as well that the speaker (in this matter it refers to the dentist) tries to affect the mental disposition of the listener (patient) through verbal and paraverbal utterances which make the structure of the patient's knowledge and attitude change as well. In this research on dental hypnosis, it is important to acknowledge that the patient is not free to give responses on the doctor's utterances, but it is tied to the utterances that are usually in the form of "commanding" from the doctor. it is possible that the patient may reject the commands given by the doctor, but he cannot avoid it since the intervention conducted by the doctor through language in this hypnosis process touch his logics and feeling, also the image of an event might be real such as imagining beach, calm sensation, and so on. (Scarvalieri, 2015). Therefore, the patient has no choice but to give responses as wanted and commanded by the therapisr or doctor. The responses may be in verbal, nonverbal, or paraverbal such as cough, and so on. Meanwhile, the following shows the perlocutionary act/responses produced by the patient toward the hypnosis dental therapist during the hypnosis practice or otherwise.

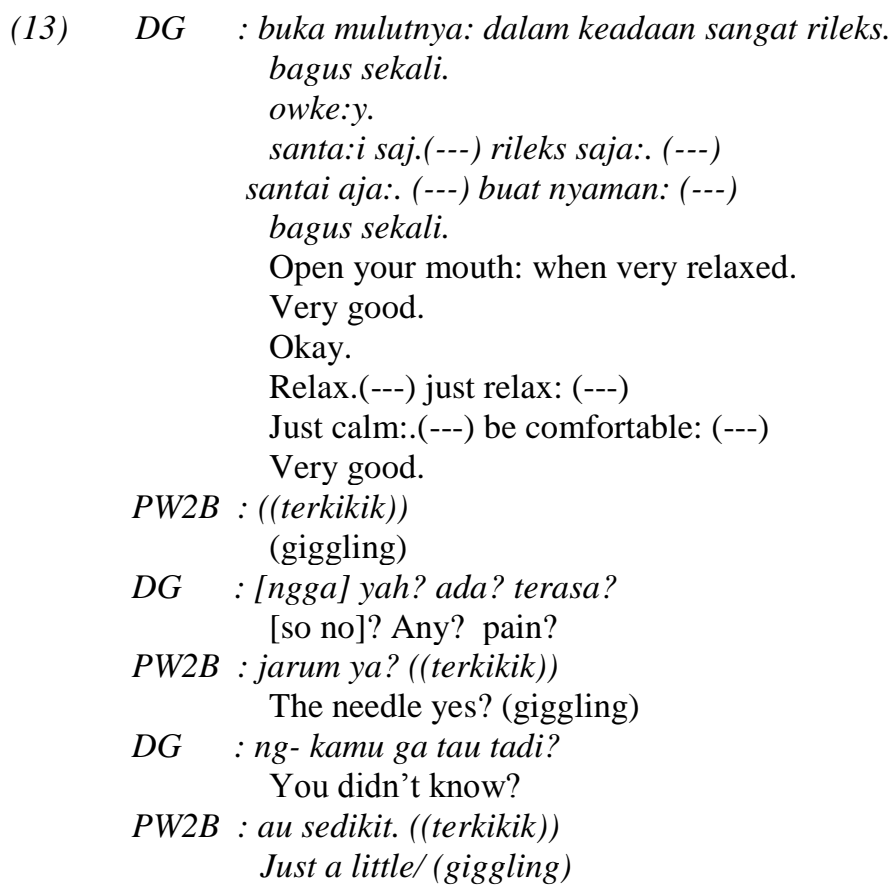


The example ofa data (13) above shows that the doctor's hypnosis practice to the patient does not always work. These three data show that the patient delivers perlocutionary act ((terkikik)) (giggling), (bertanya) jarum ya? ((terkikik)), (asking) the needle yes? (giggling); (menjawab) tahu sedikit. ((terkikik)). (answering) just a little (giggling). The acts of (giggling) and asking or answering verbally implicate "uncomfort" of the patient to recognize that the doctor's hypnosis effort does not work on him. Even though previously the hypnosis dental treatment has already been conducted by the doctor with asking the patient to open his mouth using illocotionary act that is commanding directly along with repetition and climax figure of speech.

Conversely, the failure of the hypnosis process between the patient and the dcotor in the data (14) above is also marked by the doctor's response by asking back to the patient in the transcription [ngga] yah? Ada? Terasa? ([so no] yes? Any? Pain?). this means that as long as the verbal dialogue still continues between the doctor and the patient, the hypnosis dental process does not succeed yet to reach the patient's subconsciousness. The process is conducted one more time until the doctor can reach the patient's subconsciousness, because based on research there are several people who need more time to be hypnotized. However, linguistically the directives speech act in the forms of repetition as well as climax figure of speech along with nonverbal and paraverbal activities such as sound emphasizing intonation and accent in certain positions accordingly, the right speed of utterance (piano,pianissimo, showing that the doctor's utterances become soft and softer) are conducted to suggest the patient into the subconsciousness.

\subsubsection{Figure of Speech in the Hypnosis Therapy}

Figure of speech during conversations are often used for various purposes. It is the same as in the hypnodontic. The figure of speech is used as a strategy to affect patient. There are four figures of speech identifiedin the hypnodontic, namely (1) climax, (2) parallelism, (3) antithesis, and (4) repetition.

\section{a. Climax Figure of Speech}

Climax describes the order of the notions which are increasing or going up (Nurhadi, 2013: 49). It is similar to explaination by Keraf (2009: 124) stating that climax is a figure of speech conveying notions' order which is going up of its importance from the previous notions. Pay attention to the following data.

(15) Baik, sekarang saya akan menghitung mundur mulai 3 sampai 1 dan rasakan bahwa setiap saya menghitung, terasa bahwa mata Anda semakin terkunci dengan rapat. Ya, tiga, semakin rapat, dua, semakin kuat, satu, kini mata Anda benar-benar terkunci. (ST/08)

Ok, now I will count down starting from 3 to 1 and feel that in every count, your eyes will be getting heavier and locked. Yes, three, getting tighter, two, getting heavier, one now your eyes are completely locked.

(16) Bapak mengantuk tak dapat ditahan lagi... bila saya menghitung sampai tiga, Bapak akan menutup mata dan tidur.... Ya... satu... mata semakin berat... dua... Bapak tak kuat membuka mata lagi... tiga...tutup mata Bapak dan tidur....tidur...Bapak terus tidur (Gl/01)

You feel very sleepy and cannot resist anymore... if I count to three, you will close your eyes and sleep...Yes...one...your eyes are getting heavier...two...you cannot open your eyes anymore...three..close your eyes and sleep...sleep...you keep sleeping

Data (15)-(16) contain climax figure of speech. There is order of notions' importance which is getting higher. The order in data (15) refers to bahwa mata anda semakin terkunci dengan rapat. Ya, tiga, semakin rapat, dua, semakin kuat, satu, kini mata anda benar-benar terkunci. (your eyes will be getting heavier and locked. Yes, three, getting tighter, two getting heavier, one, now your eyes are completely locked). This climax's order makes a series of steps in which every step gone through by the patient makes the patient relaxed from the body to his head until all is completely relaxed 
It is the same as in data (16), there is climax figure of speech marked by the use of counting down followed by the suggestion in each count. Therefore, every count continues to make the patient experience the steps starting from mata berat (your eyes are getting heavier), then tak kuat membuka mata (cannot open your eyes) and to finally tertidur (sleeping).

\section{b. Parallelism Figure of Speech}

Ratna (2009:4) explains that parallelism is a figure of speech with the alignment of words or phrases having the same functions. It is similar to Nurhadi's opinion (2013:106) that parallelism describes the alignment of the elements in a construction. Pay attention to the following data.

(17) Ya kini tangan Bapak menjadi kaku seperti batang besi, seperti batang besi sehingga Bapak tak mampu membengkokkannya. (GL/1)

Yes, now your hands will be stiff like an iron rod, like an iron rod which you cannot bend.

(18) Tidur... Bapak terus tidur... Bapak merasa berayun-ayun di atas awan.... Di sekeliling Bapak sangat hening... sunyi... dan senyap. (GL/1)

Sleep....Your keep sleeping...you feel swayed on the cloud...around you is very serene....quiet... and silent.

The two data above contain parallelism figure of speech. In the data (17), the parallelism is shown by the alignment between tangan kaku (stiff hands) and batang besi (iron rod). These parallels ease the patient to imagine the form of the hands' stiffness in which in his mind he imagines his hand become iron rod. If the patient understands the intention, the patient's hands will be difficult to bend as in bending iron. The data (18) has alignment in the phrases of hening (serene), sunyi (quiet), and senyap (silent). These three words possess the same meaning. It strengthens the suggestion making the patient more relaxed in his sleep.

\section{c. Antithesis Figure of Speech}

Keraf (2009: 126) states that antithesis is a figure of speech containing contradictive ideas, with the use of opposite words or group of words. .

(19) Meskipun Bapak tidur dengan lelap, diri Bapak masih dapat membuka mata, ya bukalah pelanpelan.... (Gl/01)

Although you are sleeping tight, you can still open your eyes, yes open them slowly....

(20) Katakan pada mata Anda: Mata, kamu, aku perintahkan terkunci dengan sangat kuat dan tidak ada kekuatan apapun bisa

membukamu! Semakin kau berusaha membuka justru kau semakin

terkunci lebih kuat lagi! (ST/07)

Say to your eyes: Eyes, you, I command to be locked very strongly and there is no power which can open you! The more you are trying to open, the stronger you are getting locked!

in the data (17) and (18), there are antithesis shown by the contradictive notions between the group of words tidur dengan lelap (sleeping tight) and masih dapat membuka mata (can still open your eyes) along with terkunci (locked) and membuka (open). However, in the hypnosis state, one may open his eyes. Thus, there are contradictive ideas in those sentences.

\section{d. Repetition Figure of Speech}


Repetition is repeating words, group of words, in the beginning, middle, and end of sentence. It can be said that repetition is one of the main feature in hypnosis. This is due to the fact that the repetition gives confirmation and affirmation toward the suggestion given. Pay attention the following data.

(21) Anda bayangkan dan rasakan dan pikirkan bahwa Anda telah menjadi lebih langsing, lebih langsing, lebih kurus, lebih kurus, otot-otot menjadi kencang, bentuk badan ideal sepenuhnya. (WR/03)

You imagine and feel and think that you have become slimmer, slimmer, thinner, thinner, muscled, complete ideal body.

(22) Bapak tidur terus.... Oke, ya tidur, bagus, luar biasa, tidur semakin lelap, semakin lelap, semakin lelap ya semakin lelap dan semakin lelap. (Gl/1)

You keep sleeping...okay, yes sleep, good, amazing, sleep tighter, tighter, tighter yes getting tighter and tighter.

Data (21)-(22) contain repetition. It is marked by the repetition of words and phrases. In the data (21), there is repetition in the phrase lebih langsing, lebih langsing, lebih kurus, lebih kurus (slimmer, slimmer, thinner, thinner). While in the data (22) there is repetition in the word bagus (good). The repetition functions to confirm the suggestion given. For example in the data (22), the repetition as if it gives steps of sleep making semakin lelap (tighter) is repeated often resulting in semakin lelap (sleeping tighter).

\section{Conclusion}

The result of analysis shows that a doctor conducting hypnosis dental communication toward her patient has used linguistic features in her speech strategies. The steps of hypnosis dental vommunication are divided into two namely introduction and act/treatment. In the introduction, a hypnodontist generally uses Assertives-Stating speech act. This is due to the fact that in the beginning of the communication (introduction), the hypnodontist gives more information on the treatment that will be conducted to her patient. Meanwhile, in the act/treatment, the hypnodontist has already given mild suggestions to the deep ones to her patient. In this step, the most used types of speech act are Directives-Commanding and Expressive-Praising.

Furthermore, the types of speech act used by the hypnodontic therapist are Direct-Commanding Speech Act, Direct-Stating Speech Act, and Indirect-Stating Speech Act. It is based on the fact that a dentist realizes certain various commands and appreciations to her patient when he follows any given order. The aim and intention of the utterances wanted by the dentist during the hypnodontic therapy are to give certain suggestions in order for the patient to feel less painful during the medical treatment.

The analysis result shows that the perlocutionary act/responses produced by the patient toward the dentist conducting hypnosis dental practice may be in verbal, nonverbal, and paraverbal such as laughing. In the (1) introduction step, the responses produced are mostly in verbal. It is caused by the fact that in the introduction step, the patient's consciousness level does not completely enter the subconciousness. This means that the patient can still hear, digest, ask, and answer what being said by the doctor. Meanwhile, in the (2) act/treatment step, the patient shows more nonverbal responses or very short verbal responses, or paraverbal responses such as laughing. In this step, the patient's consciousness level has already begun entering the subconsciousness. In addition to marking the introduction and act/treatment steps, the perlocutionary act in the forms of verbal and nonverbal or paraverbal marks as well whether it succeeds or not the hypnosis dental process conducted by the dentist.

Furthermore, it can be observed as well that the dentist conducting the hypnodontic practice also uses several figures of speech in her utterances, namely climax, parallelism, antithesis, and repetition. All the language strategies used aim to give suggestion to the patient in order for him to feel less painfull during the medical treatment. 


\section{Acknowledgement}

This study was supported by the Research Fund provided by Hibah PUPT Kementerian Riset dan Pendidikan Tinggi, Republik Indonesia

\section{References}

Austin, J.L. (1962) How to Do Things with Words. Cambridge, Mass: Harvard University Press.

Busch, Albert/Spranz-Fogasy, Thomas, Hrsg. (2015). Handbuch Sprache in der Medizin. (Handbücher Sprachwissen 11). Berlin/Boston: de Gruyter.

Darmayanti, N., Nurhadi, J., Yubiliana, G., (2014). "Strategi Kebahasaan dalam Terapi Hipnodontik: Suatu Kajian Pragmastilistika", Makalah Seminar Internasional Linguistik Transdisipliner Universitas Indonesia. ISSN: 2355-3642 hlm. 163-171.

Djajasudarma, Fatimah. (1993). Metode Linguistik: Ancangan Metode Penelitian dan Kajian Bahasa. Bandung: PT Eresco.

Ehlich, K. (1998). Funktionale Pragmatik - Terme, Themen und Methoden. Der Deutschunterricht in Japan 4, 4 $-24$.

Graf, E., Pawelczyk, J. (2014). The interactional accomplishment of feelings-talk in psychotherapy and executive coaching: Same format, different functions?, John Benjamins, Volume Discourses of Helping Professions, Amsterdam, p.59-90.

Heller, S., and Steele, T. (2005) Monster and Magical Sticks: There's No Such Things Hypnosis. Arizona: New Falcon Publications.

Hickey, Leo. (1993). "Stylistics, Pragmatics and Pragmastylistics". Dalam: Revue belge de philologie et d'histoire. Tome 71 fasc. 3, 573-586.

Ibrahim, Abdul Syukur. Kajian Tindak Tutur. Surabaya: Penerbit Usaha Nasional.

Leech, Geoffrey. (1983). Principles of Pragmatics. London. Longman.

Nurhadi, Jatmika. (2013). "Tuturan Hipnoterapi dalam Bahasa Indonesia: Suatu Kajian Pragmastilistika". Bandung: Tesis Program Pascasarjana Fakultas Ilmu Budaya Universitas Padjadjaran

Rehbein, J., \& Kemeyama, S. (2004). Pragmatik. In U. Ammon, N. Dittmar, K. Mattheier, \& P. Trudgill, Sociolinguistics/Soziolinguistik. An International Handbook of The Science of Language and Society. 2nd completely revised and extended edition. 3 Teilbände, Tb. 1 (S. 556 - 588). Berlin, New York: de Gruyter.

Ratna, Kutha Nyoman. 2009. Stilistika: Kajian Puitika Bahasa, Sastra, dan Budaya. Yogyakarta: Pustaka Pelajar.

Rehbein, J., \& Kemeyama, S. (2004). Pragmatik. In U. Ammon, N. Dittmar, K. Mattheier, \& P. Trudgill, Sociolinguistics/Soziolinguistik. An International Handbook of The Science of Language and Society. 2nd completely revised and extended edition. 3 Teilbände, Tb. 1 (S. 556 - 588). Berlin, New York: de Gruyter.

Sudaryanto. 1993. Metode dan Teknik Analisis Bahasa. Yogyakarta: Duta Wacana University Press.

Watkins (1983). The Handbook Of Clinical Health Psychology. New York: Plenum Press

Wijana, I Dewa Putu (1996). Dasar-Dasar Pragmatik. Yogyakarta. Penerbit Andi.

Wong and Hakim (2009). Dahsyatnya Hipnosis. Jakarta: Penerbit Visimedia.

Yule, George. (1996). Pragmatics. USA: Oxford University Press.

Yubiliana. (2014). "Pengaruh Pendekatan Dental Hipnosis terhadap Dental Asietas dan Kualitas Hidup Pasien Pascapencabutan Gigi”. Bandung:Draf Disertasi Fakultas Kedokteran Gigi Unpad.

Redder, A. (2008). Functional Pragmatics. In G. Antos, E. Ventola, T. Weber, \& K. (. Knapp, Handbook of Interpersonal Communication (S. 133 - 178). Berlin: de Gruyter.

Simons, D., Potter, C., Temple, G. (2007). Hypnosis and communication in dental practice. London: Quintessence Publishing Co., Ltd.

Watkins (1983). The Handbook Of Clinical Health Psychology. New York: Plenum Press 